\title{
Some thoughts on qualitative research in psychology in Europe
}

Michael Murray,

Keele University, UK.

Correspondence: m.murray@keele.ac.uk

Pre-publication of article to be published in Qualitative Research in Psychology, 2019, Vol. 16, No.

3, 508-512

http://doi.org/10.1080/14780887.2019.1605279

If we trace the origins of psychology back to nineteenth century positivism, we can see that concern about measurement was a defining characteristic that was used to differentiate psychology from other social/human sciences. The dominant voices in psychology defined it as a natural science that could measure all those psychological entities that existed 'out there' in the same way as other natural scientists measured rocks and other physical entities. This search for scientific respectability and credibility is reflected in the debates about statistics and more recently about replicability which is frequently reported in these contributions.

But there have been alternative approaches which can be traced back to at least Wundt whose work was selectively used to buttress the growth of experimental methods despite having a much more expansive perspective (see Wong, 2009). Debates on these approaches have continued throughout the twentieth century and especially came to the fore at times of social unrest when there was questioning of the value of social science. This collection of articles describes the re-emergence of qualitative research in Europe over the past forty years and some of the challenges faced by qualitative researchers. Looking back, we can begin to see some commonalities in these challenges which are not just concerned with method but also about epistemology and the purpose of psychology. 
In the 1910s, the classic five volume work by Thomas and Znaniecki on Polish immigration to the United States documented the everyday experiences of immigration but also promoted discussion about the nature of social science. These volumes included material from diaries and letters as well as an autobiography and generated substantial debate about qualitative work (see Sinatti, 2008). One of the commentaries was by Gordon Allport who in the 1930s was conducting a detailed study of the life histories of refugees from Nazi Germany. He commented that it was 'autobiographies that give unaccented accounts of ordinary experience' (Allport, 1942; see Murray, 2002). This concern with exploring the everyday experience of the marginalised was also reflected in the work of Robert MacLeod (1907-1972) whose article in Psychological Review entitled 'The phenomenological approach to social psychology' concluded that 'the goal of science as science is not prediction and control but understanding' He continued: 'If we can understand the world as it is structured for the other person [...] we shall have made one small step towards the resolution of the conflicts that beset us' (MacLeod, 1947: 53).

Caillaud et al (2019), in this collection, note how Serge Moscovici was happy to use a variety of methods in his early work on social representations of psychoanalysis. Moscovici had arrived in Paris having travelled as a refugee through the devastation of Europe following the second world war. France was still in turmoil and Moscovici described his early days in the Sorbonne as his 'age of innocence' when he did not have contact with others working in social psychology, 'especially no contact with American colleagues' (Moscovici \& Markova, 1998). Apfelbaum (2009) described this generation of social psychologists at the Sorbonne as 'a generation without forefathers' (p. 10). It was in these early days that Moscovici used such methods as diary questionnaires, interviews and newspaper analysis as his methodological tools. His aim was to develop a sophisticated understanding of 'common-sense' and 'to rehabilitate common knowledge which is grounded in our language and in our daily life' (Moscovici \& Markova, 1998, p. 375). But Moscovici went further, especially in his work on minority influence, to argue for a role for psychologists in challenging social oppression.

This freedom to develop qualitative research methods and to combat social injustice was also apparent more recently in Europe in those countries which emerged from communist and fascist tyranny. Kovacs et al (2019) stress the importance of the socio-political and historical context in their exploration of the adoption of qualitative methods in central/eastern Europe. Masaryk et al (2019) recall the excitement of those early days in Czechoslovakia when psychologists were not only developing new methods but challenging deliberately the established orthodoxy of a totalitarian regime. From the outset, a common concern was to reflect the voice of the marginalised and the oppressed and to consider ways to work with the researchee in a collaborative manner. This was 
the age of great expectations. The excitement of the early encounters between psychologists from the East and the West in the 1970s is vividly described in the comments of Wendy Stainton Rogers and others. Eros (2010, in Masaryk et al 2019) recalled the lecture by Moscovici in Hungary in 1974 to a group of social psychologists from Eastern Europe which coupled the need for theoretical and methodological innovation with the need for social change.

In the UK, the challenge to the dominant quantitative orthodoxy followed the crisis in social psychology which emerged in the 1970s and which was followed by the so-called 'turn to language' which was reflected in the concern with everyday accounts (Harré \& Secord, 1973) and then with forms of discourse (Potter and Wetherell, 1987; Parker, 1989). These ideas meshed somewhat with social representations theory although there continues to be tensions between these approaches despite attempts at rapprochement (see Battel \& Castro, 2018).

The early enthusiasm for qualitative methods has now moved to a second period On the one hand there was the awareness that the scientific establishment often ignored or denigrated these new methods and that forms of social change were difficult to pursue within academia. It was also the time of increasing state surveillance of research.

Apfelbaum (2009) in her discussion of the conflict experienced by critical voices which began to emerge within social psychology in the 1970s described the processes as 'degrouping' whereby the dominant group marginalises and excludes the minority. These processes include 'creating a mythical standard and applying it as a universal law or denying diversity to stigmatise a group and exclude its members' (p. 20). She noted that this process of degrouping is not just on an academic level but also at a personal level such that the minority are disparaged and excluded from social and academic opportunities including publications, events, funding, awards, etc. Many qualitative researchers will have experienced the frustrations at being excluded from these opportunities which seriously threatened their career advancement. In their study of qualitative researchers in Spain, Gemignani et al (2019) describe 'the general othering of qualitative researchers, and their relegation to a secondary role in dominant scientific circles'.

But this process of degrouping can be frustrated by the minority group regrouping and fighting back. This is the process described by Reilly et al (2019) in their efforts to subvert control of the research review process currently underway in the UK. It is through this process of regrouping that minority ideas can develop. However, the process of regrouping takes time and it can be frustrating having to play by the rules laid down by the majority quantitative research community (Branney et al, 2019). Several of the contributions expressed concern at the increasing surveillance of research in general which has led to the marginalisation of qualitative research in psychology. For some this has led to a 
certain amount of demoralisation. The development of a European Society of Quality Psychology is an important initiative which can provide support to qualitative researchers. However, in developing its own organisations qualitative research should not leave behind its original critical impulse.

One way of combatting accusations of unreliability has been to use mixed methods which as Kovacs et al (2019) note is often accompanied with a substantial amount of 'paradigmatic eclecticism and confusion'. An alternative is the use of triangulation which instead of trying to shoe-horn qualitative methods into a positivist box, overtly explores the contribution of divergent methods, theories and epistemologies (Caillaud et al, 2019; Restivo \& Apostolidis, 2019). This formulation which has been especially championed by Flick (2017) is one that needs to be explored more.

This collection has highlighted the challenges faced by qualitative researchers in psychology throughout Europe. To move forward we need to reflect on past developments as well as consider the changing socio-political climate in which we live. Early qualitative researchers aimed to address pressing social problems of immigrants and refugees. Today in Europe we face similar social challenges. It is not just the turmoil faced by refugees from outside Europe but also the ongoing mass migrations within Europe and the impact of neoliberalism on everyday lives Flick (2018) has also recently taken up this issue in his discussion of qualitative methods in the neo-liberal age. This is a most welcome intervention. Neoliberalism devalues the role of the state and emphasizes the responsibility of the individual. It widens social inequalities and hollows out public institutions threatening the lives of the most disenfranchised. What can qualitative researchers do to expose the impact of these policies and enhance the prospects of those who are excluded. The original social justice agenda that inspired many early qualitative researchers cannot be jettisoned at a time of state surveillance of research. It also means challenging notions of fake news and populist criticisms of science and to look for allies in the other social sciences (Montali et al, 2019) and the humanities (e.g., Stonebridge). Qualitative researchers need to reflect upon their aims and assumptions and how they can work with others to subvert the myriad forms of oppression. It means moving beyond a focus on the interview to consider other sources of 'data' (Flick, 2018), working with the researchee rather than imposing interpretive frameworks and exploring new participatory methods. These are challenging but exciting times if we reflect upon both our values as well as our theories and methods. 
20 Jan 2019 


\section{References}

Apfelbaum, E. (2009). Against the tide: Making waves and breaking silences. In L.P. Mos (ed.) History of psychology in autobiography (pp. 1-36). New York: Springer.

Batel, S., \& Castro, P. (2018). Reopening the dialogue between the theory of social representations and discursive psychology for examining the construction and transformation of meaning in discourse and communication. British Journal of Social Psychology, 57, 732-753.

Branney, P., Reid, K., Frost, N., \& Woolhouse, M. (2019). A context-consent meta-framework for designing open data studies; a telephone-interview study of the practical and pedagogical issues of open qualitative data sets for psychologists. Qualitative Research in Psychology, 16,

Caillaud, S., Doumergue, M., Préau, M., Haas, V., \& Kalampalikis, N. (2019). The past and present of triangulation and social representations theory: a crossed history. Qualitative Research in Psychology, 16,

Flick, U. (2017). 'Mantras and myths': the disenchantment of mixed-methods research and revisiting triangulation as a perspective. Qualitative Inquiry, 23, 46-57.

Flick, U. (2018). The concepts of qualitative data: challenges in neoliberal times for qualitative inquiry. Qualitative Inquiry, On-line, 1-8.

Gemignani, M., Ferrari, S., \& Benitnez Baena, I. (2019). Rediscovering the roots and wonder of qualitative research in Spain: a cartographic exercise. Qualitative Research in Psychology, 16,

Harré, H.R., \& Secord, P.F. (1973). The explanation of social behaviour. Oxford: Blackwell.

Kovacs, A., Kiss, D., Kossai, S., Pados, E., Kalo, Z., \& Racz, J. (2019). Mapping qualitative research in psychology across five Central-European countries: Contemporary trends; a paradigm analysis.

Qualitative Research in Psychology, 16,

MacLeod, R.B. (1947). The phenomenological approach to social psychology. Psychological Review, 54, 193-210.

Masaryk, R., Petrjanosova, M., Lasticova, B., Kuglerova, N., \& Stainton Rogers, W. (2019). A story of Great Expectations. Qualitative research in psychology in the Czech and Slovak Republics. Qualitative Research in Psychology, 16,

Montali, L., Benozzo, A., Ripamonti, S.C., Frigerio, A., Galuppo, L., Gemignani, M., \& Vergine, I. (2019). Qualitative research in social and organizational psychology: The Italian way. Qualitative Research in Psychology, 16, 
Moscovici, S., \& Markova, I. (1998). Presenting social representations: A conversation. Culture \& Psychology, 4, 371-410.

Murray, M. (2002). Connecting narrative and social representation theory in health research. Social Science Information, 41, 653-673.

Parker, I. (1989) The Crisis in Modern Social Psychology, and how to end it, London and New York: Routledge.

Potter, J. \& Wetherell, M. (1987). Discourse and social psychology: beyond attitudes and behaviour. London: Sage.

Restivo, L., \& Apostolidis, T. (2019). Triangulating qualitative approaches within mixed methods designs: a proposal based on a French research in social health psychology. Qualitative Research in Psychology, 16,

Riley, S., Brooks, J., Goodman, S., Cahill, S., Branney, P., Treharne, G.J., \& Sullivan, C. (2019). Celebrations among challenges. Considering the past, present and future of the Qualitative Methods in Psychology (QMiP) section of the British Psychological Society. Qualitative Research in Psychology, 16 ,

Sinatti, G. (2008). The Polish Peasant revisited: Thomas and Znaniecki's classic in the light of contemporary transnational migration theory. Sociologica, 2, 1-21.

Stonebridge, L. (2018). Placeless people: Writings, rights and refugees. Oxford: Oxford University Press.

Wong, W.-C. (2009). Retracing the footsteps of Wilhelm Wundt: Explorations in the disciplinary frontiers of psychology and in Volkerpsychologie. History of Psychology, 12(4), 229-265. 